\title{
When do European election campaigns become about Europe?
}

\section{An analysis of parties' strategic communication in the run-up to the 2014 EP elections}

Beatrice Eugster, ${ }^{1 *}$ Carlos Jalali, ${ }^{2 *}$ Michaela Maier, ${ }^{3 * *}$ Severin Bathelt, ${ }^{3}$ Melanie LeideckerSandmann, ${ }^{4}$ Silke Adam, ${ }^{1}$ Ralph Negrine, ${ }^{5} \&$ Nicolas Demertzis ${ }^{6}$

\begin{abstract}
This article examines which parties put European issues on their 2014 European Parliament campaigns, and what influenced whether they did so, based on innovative data from the content analysis of 9,100 press releases in seven countries. Overall, established and especially governing parties did not shy away from EU issues anymore, referring to them as often as challenger parties. The likelihood of EU issues in campaigns derives from a combination of predictors from the selective emphasis and co-orientation approaches. In general, parties with high internal dissent on EU integration avoid European issues, and weak leaders will only dare talking about the EU if internal dissent is low. However, between-party-type comparisons indicate that successful leaderships of governing parties facing strong internal divisions are even less likely to put EU issues on the agenda. Regarding the co-orientation model, parties' EU focus seems to be mainly determined by the communication of (other) opposition parties.
\end{abstract}

Keywords: Strategic party communication, European election campaigns, selective emphasis approach, co-orientation thesis, content analysis 


\section{Acknowledgements and Funding}

Authorship of the first three authors is alphabetical to reflect their equal contribution. We would like to thank Jürgen Maier, Evelyn Bytzek and Sylvia Kritzinger for their comments on the data analysis as well as Eva Antl-Wittenberg and the team of Claes de Vreese at ASCOR for their help with the data collection. We also thank the two anonymous reviewers for their very helpful comments. This work was supported by the German Research Foundation (DFG) under Grant MA 2244/5-1, the Swiss National Fonds (SNF) under Grant 10017E-144592/1 and the Portuguese Science and Technology Foundation (FCT), by the Programa Operacional Competitividade e Internacionalização (COMPETE 2020) and by the Programa Operacional Regional de Lisboa (PO Lisboa), in its European Community Fund FEDER component, as part of the 'Changing European Elections' project (POCI-01-0145FEDER-016887; PTDC/IVC-CPO/3481/2014). 


\section{Introduction}

At the heart of most conceptions of representative democracy lies the notion that citizens 'decide issues', to borrow Schumpeter's (2003: 250) expression. Yet this notion of citizens deciding issues requires issues to be proffered to citizens in elections. If an issue is not presented and is silenced by parties, then voters are unable to decide it, thus having considerable implications for political decision-making. As Ware notes, 'what is filtered out of politics because neither party chooses to represent that interest or opinion, is often as important as the issue that the parties are contesting fiercely over' (Ware 1996: 7).

This notion of silencing (or filtering out) issues is particularly apposite when we consider the salience of European Union (EU) issues in European Parliament (EP) elections. Indeed, past European elections showcase extreme instances of this tendency to silence issues. Despite the EP being the only directly elected EU institution, EP elections have typically been described as second-order national elections (Reif and Schmitt 1980), with the few voters who turn out casting their votes based on domestic issues (notably, government performance) rather than European ones. Such voter behaviour appears to be the result of political parties' failure to campaign on European issues (e.g. De Vreese 2009; Hoeglinger 2016; Kriesi et al. 2012; Petithomme 2012). Scarce media coverage and media biases towards domestic rather than EU implications of the vote also appear to play a role in this context (e.g. De Vreese et al. 2006; Machill et al. 2006; Maier and Maier 2008; Schuck and De Vreese 2011).

Yet, as previous research suggests (see below), this pattern does not necessarily remain static. The salience of EU issues has seemingly grown for voters. The mismatch between voters' demand for an issue and parties' supply of it can generate opportunities for the emergence of issue entrepreneurs (De Vries and Hobolt 2012) that can potentially force 
parties to incorporate issues in their campaigns that they previously ignored. In this article, we examine the tendency of political parties to silence versus incorporate EU issues in the 2014 European Parliament (EP) election campaigns. In particular, we seek to answer the following research question: Which parties campaign on European issues, and which factors help us understand whether they do so?

Specifically, we aim to explain what leads parties' EP election campaigns to become about Europe - generating the not-insignificant possibility of voters deciding how they will vote based on European issues, thus contributing to the transparency of EP elections (Adam and Maier 2016; Boomgaarden and De Vreese 2016). With our analysis, which builds on our work on the 2009 EP elections (Adam and Maier 2011; 2016), we add to the existing literature in four ways. First, our analysis is based on a unique data set of 9,100 coded press releases issued by 46 national parties in seven countries during the 12 weeks prior to the 2014 EP elections. Press releases were chosen as as they can be published by all parties (independent from size and government participation) at all times during the campaign, representing parties' strategic communication behaviour in an unbiased way. Second, our data allows us to describe the extent to which parties referred to EU issues in their press releases and whether they did so in a cursory manner or more in-depth. Third, we assess to what extent the role of parties in the party system - such as the distinction between established parties that compete for office and challenger parties excluded from national government - explains the degree of salience given to the EU; and fourth, we test a comprehensive set of variables that potentially drive party communication, thus allowing us to assess the most prominent approaches in the field (i.e., the selective emphasis and coorientation theses).

\section{Party Campaigns in EP Elections}


Discussions about EP elections almost invariably start with Reif and Schmitt's (1980) second-order election model. This presumes that EP elections are generally fought on national issues (or 'main arena issues', as Reif and Schmitt put it), as opposed to European ones (Reif and Schmitt 1980: 14). Reif and Schmitt identified party campaigns as one of the main explanatory factors for this outcome. As Marsh (1998) observed, 'parties themselves generally work to make European elections second-order national elections' by focusing on domestic rather than European issues (Marsh 1998: 607).

This picture, however, is not static. EU issues appear to have become more important for voters, beginning in the early 1990s (Hooghe and Marks 2009). It follows naturally to question how parties respond to this potential demand. Initial work - e.g. Van der Eijk and Franklin (2004) on the 1999 EP elections - suggested a mismatch between parties' silencing of EU issues and voters' changing attitudes, creating a 'sleeping giant' of political mobilization on EU issues (Van der Eijk and Franklin 2004: 32). As a result, if the main parties remain resistant to engaging in EU issues, they can potentially open the door for political entrepreneurs, who may incorporate silenced issues into their platform and reap significant electoral gains as a result (Hobolt and De Vries 2015; Hooghe and Marks 2009; Meijers and Rauh 2016; Van der Eijk and Franklin 2004; Van de Wardt et al. 2014). Additionally, the introduction of new issues could potentially force their wider incorporation, even by parties that would prefer silence - especially on issues that have traction amongst voters, as appears to be increasingly the case with regard to EU issues.

Recent work tends to confirm these dynamics. Hobolt and De Vries (2015) find evidence of issue entrepreneurship on EU issues over a 23-year period with parties that we call here 'challenger parties' - parties that are typically excluded from access to government or fail to mobilize a relevant share of the vote - and are more entrepreneurial (see also Van de 
Wardt et al. 2014). Additionally, Adam and Maier (2016) find evidence of mobilization on EU issues in the specific context of the 2009 EP elections, suggesting a transition away from the previous second-order party campaign model, even if the campaign was likewise not centred solely on EU issues. Interestingly, they find evidence of EU politicization not only in challenger parties' communication, but also in those of 'established parties' - that is, those that are in the main sphere of competition and are typically part of government - with little difference between the two (Adam and Maier 2016; see also Jalali and Silva 2011). Adam et al. (2017) have in parts confirmed this trend in their study of the 2014 EP elections; they find that pro-European catch-all parties do not necessarily avoid European issues in their election campaigns unless they are struggling with internal dissent. At the same time, news of the complete demise of the second-order model appear to be somewhat overstated, even in the propitious context of the 2014 EP elections. As the European Parliament's own slogan put it, the 2014 EP elections were supposed to be 'different'. First, the introduction of the Spitzenkandidaten system intended to link citizens' votes in EP elections with the choice of a European Commission President. Second, the then ongoing Eurozone debt crisis put the EU on centre stage in a number of EU member-states, be they bailout recipients or donors. The European Parliament's claim that 'this time it's different' made an explicit connection with this, noting that the 2014 EP elections would "allow voters to contribute to strengthening or changing the direction that Europe takes in tackling the economic crisis" (European Parliament 2014). Finally, these elections were also potentially 'different', as the run-up to these elections provided the rumblings of a potential populist and Eurosceptic 'earthquake' (Rooduijn 2015). Yet, despite this seemingly favorable context, studies on the 2014 EP elections provide a mixed picture: while some note a potential end of the second-order model (e.g. Hobolt and de Vries 2016), others refer its enduring relevance (e.g. Franklin and Nielsen 2017; Schmitt and Teperoglou 2015; Schmitt and Toygür 2016). Overall, it appears fruitful to 
conceptualize the notion of first vs. second-order elections as a continuum rather than as discrete, separate notions (Franklin and Nielsen 2017).

Indeed, while there is evidence of increased EU salience in various parties' recent EP election campaigns, substantial differences remain between parties and across countries (Adam and Maier 2011; 2016; Adam et al. 2017). In this article, we aim to analyse in detail which factors facilitated or inhibited parties from raising EU-related discussions in their 2014 EP election campaigns. We do so by combining and testing explanatory factors from two approaches: the selective emphasis approach (RQ1 to H3), derived from the pioneering work of Budge and Farlie (1983) and Petrocik (1996), and the co-orientation approach (Steenbergen and Scott 2004; see H4a and H4b). In other words, we are interested in assessing what leads parties to 'pick up' European issues, taking into account both the intraparty (selective emphasis) factors; and inter-party systemic (co-orientation) elements.

\section{Assumptions of the selective emphasis approach}

The selective emphasis approach presupposes that parties tend to campaign on issues that are favourable to them. This may include issues that they own, such as issues on which the party is better placed and perceived as more credible compared to competing parties (Petrocik 1996). Research on issue ownership suggests that parties have weak incentive to explore different issues from those on which they have built their reputations (Hayes 2008, see also Lefevere et al. 2015). Experimental studies also confirm that parties have little to gain from campaigning on issues that are owned by their competitors (Tresch, Lefevere and Walgrave 2015) or eschewing their core issues for those with greater media salience (Ansolabehere and Iyengar 1994). 
This is not to say that issue takeovers cannot occur (e.g. U.S. President Clinton on the issue of crime, as Holian [2004] demonstrates; see also Leidecker-Sandmann et al. 2016; Wagner and Meyer 2014; Walgrave et al. 2009) or that parties entirely avoid issue dialogue or convergence, i.e. engaging in the same issues as other parties (e.g. Dolezal et al. 2014 for the case of Austria). Indeed, such convergence can be quite high, as research on US presidential and congressional elections suggests (Sigelman and Buell 2004; Sides 2006). Yet, the selective emphasis approach retains relevance: While detecting issue dialogue in the Austrian case, Dolezal et al. (2014) also find that parties gave significantly greater salience to the issues they owned (see also De Sio and Weber 2020).

The notion of selective emphasis interacts strongly with the nature of political parties. The party reputation defined by issue ownership is 'long standing' (Damore 2004: 392) and built over time with the electorate. As such, issue ownership will tend to be stronger among established parties that typically compete for power. At the same time, this means that challenger parties - that is, those typically excluded from the main arena of competition (Mair 1997) - will have incentives to engage in issue entrepreneurship by incorporating issues (and gaining ownership of issues) in order to reframe political competence away from the established parties (Hobolt and De Vries 2015).

What are the implications of this for EU issues? As noted earlier, research before the 2009 EP elections has shown that established parties typically avoided EU issues, preferring to campaign on the issues they owned. Indeed, as Geys (2012) notes, highlighting jointownership issues - which the EU tends to be for established parties - can be an electorally harmful strategy. At the same time, challenger parties seemed to incorporate new issues in order to change the nature of political competition and, in this regard, were more likely to give salience to the EU (Hobolt and De Vries 2015; Van de Wardt et al. 2014). However, since 2009 there is evidence that campaigns on EU issues are no longer restricted to 
challenger parties, with established parties also becoming more likely to voice their EUrelated positions. To take into account this possible development we pose the following first research question:

RQ1: Do challenger parties (still) give greater salience to EU issues on their campaign agendas than governing parties and established opposition parties?

Additionally, the nature of a party's policy platform may also depend on the party's internal dynamics. In this context, we emphasize two dimensions: first, the degree of party cohesion on the issue; and second, the nature of party leadership. With regard to the former dimension, it should be noted that issue entrepreneurship carries risks. In particular, as a new issue gains salience, it risks exposing inner party divisions that had previously lain dormant. So, while giving salience to a new issue seeks to upset the apple cart of inter-party competition, it also risks intra-party dissonance (for empirical evidence, see Adam et al. 2017). The more delicate the intra-party balance, the costlier the adoption of issue entrepreneurship is and the less likely it becomes (Hobolt and De Vries 2015; Van de Wardt et al. 2014). As such, we formulate the following hypothesis:

H1: Parties are less likely to include EU issues on their campaign agenda if they are internally divided on the issue.

The other internal dimension refers to the strength of party leadership and how this interacts with party cohesion in established parties. Here, the point of departure is that parties generally have some degree of internal disunity on particular issues - especially on issues like the EU that cut across established parties. Within this context, a strong party leader - that is, 
one who has been electorally successful - can muffle internal disunity and avoid these internal divisions from emerging in a campaign (Parsons and Weber 2011). Conversely, a weak leader - that is, one who stays in office or follows electoral losses - is unable to muffle these internal divisions and, in such circumstances, the cross-cutting issues are more likely to emerge on the party's policy platform (Parsons and Weber 2011). Further, these effects are dependent on the timing of the European elections, as parties' 'organizational politics are structured foremost by national electoral cycles' (Parsons and Weber 2011: 385). Indeed, the literature stresses that, after the mid-term point in the electoral cycle, strong leaders are more likely to muffle divisive issues as national elections approach, while weak ones are increasingly unable to do so (Parsons and Weber 2011). We expect this pattern to occur in established parties rather than challenger parties, because the latter are generally less prone to the cross-cutting cleavages of the former. Indeed, Parson and Weber's (2011) pioneering work on muffling applies this concept solely to mainstream parties. We, thus, hypothesize the following:

H2a: Established parties with internal divisions on EU issues and weak leadership are more likely to put EU issues on their campaign agendas than their counterparts with strong leadership.

$\mathrm{H} 2 \mathrm{~b}$ : The further away the date from midterm, the more likely it is that established parties with weak leadership will put EU issues on their campaign agendas than their counterparts with strong leadership.

Another aspect of 'electoral considerations' has been introduced by Steenbergen and Scott (2004, p. 168). They argue that parties also need to take into account the distance between the 
position they represent regarding an issue and the voters. They claim that a party has an incentive to 'de-emphasize' (p. 168) an issue if the party's position is not congruent with the national public opinion, and, conversely, to emphasize the issue 'if the party's position on an issue is close to that of the electorate', so as to 'maximize electoral success'. Their assumption is supported by an analysis of expert ratings of parties' EU salience between 1984 and 1996. In line with this argument and these findings, we also assume:

H3: The more congruent a party's position is with citizens' opinion regarding EU integration, the more likely a party is to put EU issues on the agenda.

\section{Assumptions of the co-orientation approach}

The selective emphasis approach suggests little interaction between different parties' campaigns, as each focuses on its own positions. Campaigns are thus a series of different monologues by each party. The co-orientation approach, however, suggests that parties' platforms are considerably more adaptable and responsive to the wider issue agenda because no party has monopolistic agenda control (Steenbergen and Scott 2004). In other words, even if parties want to engage in a monologue, they will find it difficult to avoid dialogue.

Moreover, while parties react to the party system agenda, they also shape it - and indeed seek to reshape it to further their electoral interests. In this regard, the expectation is that opposition, and especially challenger parties have greater leeway than governing parties (Green-Pedersen and Mortensen 2010). The latter are bound by their policy records, which inevitably enter the party system agenda and must be defended. The former have no record to respond to and can choose which issues to criticize the government on; thus, they potentially have more influence on the party system agenda (Green-Pedersen and Mortensen 2010). 
Adam and Maier (2016) find first evidence for such co-orientation of governing parties in the context of the 2009 EP election campaigns. Their analysis shows that government parties - in contrast to earlier EP campaigns - systematically addressed European issues. They argue that 'mainstream parties might not be able to avoid the topic any longer as they do not want to leave the floor to the Eurosceptic parties' (2016: 159). Based on these ideas, we expect that:

H4a: The salience of EU issues on governing parties' agendas will be positively associated with the EU salience on the agendas of opposition parties.

H4b: The salience of EU issues on challenger parties' agendas will be independent from EU salience on the agendas of governing parties.

In the following sections, we will refer to the methodological aspects of our analysis before moving on to the results.

\section{Methods}

To test our hypotheses, we analysed national political parties' public communication in the run-up to the 2014 EP elections. To facilitate international comparisons and generalization of our findings, we focused on seven European countries: Austria, France, Germany, Greece, the Netherlands, Portugal and the United Kingdom (UK). ${ }^{1}$

\section{Material and Content Analysis}

\footnotetext{
${ }^{1}$ Countries were selected in order to represent different degrees of citizens' Euroscepticism (Eurobarometer and election results), Euroscepticism on the party level, previous government participation of Eurosceptic parties as well as parties' internal cohesion regarding EU integration.
} 
To study parties' strategic communication several data sources have been taken into account in research so far (e.g. parliamentary questioning, political speeches, manifestos, campaign ads and posters, TV spots etc.). All these data sources have their strengths but also their shortcomings (Hopmann et al., 2012; Netjes and Binnema, 2007). Press releases seem to be the most appropriate data source for our study for several reasons: First, press releases can also be published by smaller parties, which often cannot afford to produce (several) campaign spots (Hopmann et al. 2012). Second, they allow parties to put out more complex and explicit arguments regarding the EU than would be possible with, for example, campaign posters. Third, as press releases can be published independently from fixed schedules throughout the campaign (different than, e.g. parliamentary questionings and manifestos) their content is more flexible. Parties can decide to launch a press release either actively pushing a specific issue or in reaction to events (e.g. media coverage, activities of other parties or public opinion polls). Fourth, the higher frequency of press releases allows more observations of strategic communication behavior than with a tool that is only used once during a campaign, such as a manifesto. Fifth, compared to media reports, press releases represent the parties' positions free from media bias (Adam et al. 2019). Last but not least, research has shown that due to limited resources and time pressure journalists increasingly rely on easily accessible information such as press releases (e.g. Hopmann, 2012). This demonstrates the relevance of party press releases also in the overall campaign context.

Our analysis examines 9,100 press releases issued by 46 national parties (and party coalitions) in the 12 weeks prior to the 2014 EP elections. This sample includes all parties that won at least three per cent of the vote in the last European or national election before the 2014 EP elections and that participated in the 2014 EP elections (see Web appendix). ${ }^{2}$ Press

\footnotetext{
${ }^{2}$ For Germany and the United Kingdom, we collected the press releases from party archives and party homepages. For Austria, all press releases were available from the Originaltext-Service GmbH (OTS). We chose national instead of European parties as European elections and campaigns take part mainly in the national arena.
} 
releases were subject to a partly automated, partly manual quantitative content analysis (see the paragraph below on dependent variables). To ensure the reliability of manual coding (for the complete codebook, additional materials and data files, see Adam and Maier 2018), nine coders participated in a comprehensive training program, followed by a (researcher-coder) reliability test of 25 press releases each. We tested for coding reliability using Holsti's $r$ and Krippendorff's alpha coefficients. Reliability tests delivered satisfactory results with mean values of 0.98-1.00 for Holsti's $r$ and 0.97-0.99 for Krippendorff's alpha for formal categories and mean values of Holsti's $r=0.86-0.87$ and 0.82 for Krippendorff's alpha for content characteristics (main issue and issue-scope) across the seven countries.

\section{Dependent Variable - EU Issue Salience}

The salience of EU-related issues in press releases was operationalized in three steps. First, using an electronic search string that contained relevant keywords and word components, ${ }^{3}$ we examined whether a press release referred to European issues, European policies, European institutions, European politicians, or the European Parliament elections at least twice to ensure that it substantially dealt with EU matters (see Schuck and De Vreese 2011). This search identified 2,671 press releases that contained at least two references to European issues and 6,429 press releases with none or only one EU reference.

Second, those press releases containing at least two EU references were subject to a manual content analysis that, among other variables, determined the main issue of each press release and the issue-scope attached to it. The issue-scope describes whether the main issue was discussed by referring to the EU or to another political level (e.g. the national level or an

\footnotetext{
${ }^{3}$ The (English-language) search string contained the following keywords and word components: Europ*, europ*, EU, EP, EC, ECB, EIB, ESM, EFSF, EFSM, ECJ, EEAS, EESC, EIF, EDPS, EMU, Troika, troika, Frontex, FRONTEX.
} 
international level other than the EU; Koopmans 2002). Of the 2,671 press releases with at least two EU references, 2,202 were coded as primarily having an EU scope. The information from both procedures (automated detection of EU references and manual coding of issuescope) was used to define our dependent variable by generating three categories 0 (none or only one EU reference; 6,429 press releases), 1 (at least two EU references, but no EU issuescope; 469 press releases), and 2 (at least two EU references and EU issue-scope; 2,202 press releases). The three categories represent nationally focussed press releases (category 0), symbolic EU focus (category 1) and EU focussed press releases (category 2). As our goal is to assess EU salience in general, we do not distinguish between constitutive and policyrelated European issues (Braun et al. 2006).

In a third step, the overall percentages of categories 1 and 2 versus the baseline of press releases with none or only one EU reference (category 0) was calculated at the party level and used as the continuous dependent variable with a range from $0 \%$ to $100 \%$ indicating linear regression models.

\section{Independent Variables}

The data used to assess the independent variables derive from several sources: the 2014 Chapel Hill Expert Survey (Polk et al. 2017), public archives, Eurobarometer 81.4 (May 2014; European Commission 2015), as well as our 2014 analysis of EP election media coverage (see Adam and Maier 2018).

First, our analysis is based on the distinction between three groups of parties: (a) 'established governing parties', defined as those political parties governing or being part of governing coalitions at the time of the 2014 EP elections $(\mathrm{N}=12$ parties; 2,845 press releases), (b) 'established opposition parties', defined as parties that were in opposition at the 
time of the 2014 EP elections but which had previous government responsibility $(\mathrm{N}=10$ parties; 2,045 press releases) and (c) 'challenger parties', defined as opposition parties that have never been involved in government (De Vries and Hobolt 2012) for a full legislative period $\left(\mathrm{N}=24 ; 4,210\right.$ press releases; source: Döring and Manow 2016) ${ }^{4}$

In line with our theoretical expectations and hypotheses, the remaining independent variables are grouped into three blocks to account for (a) variables derived from the selective emphasis thesis ( $\mathrm{H} 1$ to $\mathrm{H} 3)$, (b) variables derived from the co-orientation thesis (H4a and H4b) and (c) control variables.

Referring to the selective emphasis thesis, five original variables and three interaction variables are used: Inner party dissent (see Parsons and Weber 2011) regarding EU integration is operationalized using the mean value of the party's dissent variable in the 2014 CHES data (Polk et al. 2017), ranging from 0 (party completely united) to 10 (party completely divided).

Past electoral performance - which we use as a measure for strength of leadership, following Parsons and Weber (2011, p. 390) - is calculated by the difference between the vote share the party obtained in the last national election and the second-last national election (source: public archives). This replicates the operationalization suggested by Parsons and Weber (2011). We recognise that leadership strength does not solely depend on past electoral performance, and other implementations can be conceived (and indeed tested in future research), such as parties' showings in polls. However, as Parsons and Weber (2011) note, while leaders' strength can depend on several factors, one that it certainly depends on is electoral success, with winning leaders seeing their internal authority strengthened, while losing leaders are either weakened or replaced by new incumbents who lack the internal legitimacy of electoral success (Parsons and Weber 2011). Thus, maintaining this rationale,

\footnotetext{
${ }^{4}$ An overview of the classification of parties is provided in the Web appendix.
} 
we take a party's past electoral performance as a reasonable (even if obviously not perfect) indicator of its leader's strength.

For political parties that participated for the first time in the last national elections (e.g. AfD in Germany and NEOS in Austria), the vote shares of the last national elections are rated as gains in votes. For parties that participated in the second-last national elections but not in the last national elections, the vote shares of the second-last national elections are rated as losses. The timing of the 2014 EP election within the national election cycle (see Parsons and Weber 2011) is measured as the absolute difference in number of days between the 2014 EP election and the midterm (middle between the last and next national election). We first divide this figure by the number of days between the midterm and the election day in order to get the proportion of the legislative period that has passed by the midterm and then square the term. Higher values indicate that national elections are closer than the midterm (the numbers of days to the midterm range from 231 days in Greece to 564 days in the UK). This variable accounts for a supposed $\mathrm{u}$-shaped structuring effect of the national election cycle with the strongest effect on EU salience at midterm (Parsons and Weber 2011). Party's EU-support is measured using the mean value of the party's position on EU integration in the 2014 CHES data (Polk et al. 2017). Citizens' EU-support is measured as the percentage of citizens in a country who evaluated the EU's image as very positive or fairly positive in the Eurobarometer survey 81.4 (May 2014; European Commission 2015; UK: 21.4\%; GR: 22.9\%; PT: 30.1\%; AT: 33\%, NL: 33.3\%; DE: 35.7\%; FR: 36.7\%). All five variables are z-standardized, as they are also included in three interaction terms. The first interaction term comprises a combination of past electoral performance (as a measure of leadership strength) and inner party dissent. The second interaction term includes this measure for leadership strength and election cycle, while the third one jointly considers EU-support of parties and citizens. 
To assess co-orientation between parties (Steenbergen and Scott 2004), the EUemphasis in the press releases from all (other) a) governing and b) opposition parties within the same country is calculated, always excluding the party under consideration (see Adam and Maier 2011; Steenbergen and Scott 2004).

Additionally, two control variables are included in the analysis to account for any effects of media EU-coverage ${ }^{5}$ as well as the extremity of a party's EU-position (see e.g., Braun et al. 2016). EU-salience in the national media is measured based on our own 2014 media content analysis (see Web appendix). The extremity of the party's EU position is measured by subtracting four points from the party's CHES data on EU support, described above, and using only the absolute value from this procedure. This variable takes values from 0, indicating mainstream positions towards the EU, to 3, indicating extreme EU positions either positive or negative.

\section{Modelling}

The results are estimated using separate (per types of party) linear-mixed-models with a random intercept at the country level. This estimation approach accounts for the hierarchical structure of the data at hand, as the 46 parties are nested in seven countries. The intraclass coefficient (ICC) shows that $11.5 \%$ (all parties included) of variance (if the EU is mentioned twice; category 1) can be attributed to clustering within countries $(7.7 \%$ if challenger parties are excluded). This finding supports the use of hierarchical models, even if the number of countries is rather small, as they allow controlling for possible mean differences in EU

\footnotetext{
${ }^{5}$ Research has shown that parties' strategic communication seeks to influence the media agenda but also takes into account issue salience in the national media under certain conditions (e.g. Thesen, 2013; Van Aelst and Walgrave, 2011; Vesa et al., 2015; Vliegenthart and Montes, 2014). In the context of this article, we follow the argument of Van der Pas (2014: 43-44) who claims that 'political actors have a choice whether to react or not to what the media are covering, and often consider this carefully'. As a result, EU salience in the national media coverage seems to be a relevant control variable.
} 
salience at the country level. In addition, we re-run the analyses using logistic regression and also excluding one party (or country) at the time to test for the robustness of the results. The findings overall corroborate the ones presented below and show that we do not overestimate the relevance of individual predictors (all robustness checks can be found in the Web appendices).

\section{Results}

Table 1 displays the differences in EU salience in the 2014 EP campaigns between party groups in the seven countries included in the study. The results show that, during the 2014 EP election campaigns, established and especially governing parties no longer avoided talking about EU matters (total per cent of press releases that mentioned the EU at least twice governing parties: 35.1 per cent; established opposition parties: 24.8 per cent; challenger parties: 27.6 per cent). In four of seven countries (i.e. Austria, Greece, Portugal and the UK), governing parties even mentioned EU matters significantly more often than both established opposition parties or challenger parties. In France and the Netherlands, opposition parties in general attached more salience to EU issues than did governing parties; whereas, only in Germany were challenger parties a bit ahead of the established parties in this regard. Nonetheless, there was a considerable variance in the salience that party groups in the different countries attached to the EU, with, for example, Portugal's governing parties mentioning the EU at least twice in 57.6 per cent of their press releases, while in France governing parties staying below 10.1 per cent. Variation on the party level was even higher. Based on these first findings, the preliminary answer to our research question 1 is that challenger parties did not attach greater salience to EU issues in their 2014 campaigns than established or especially governing parties. The first indications of this were already detected 
in the 2009 EP election campaigns (Adam and Maier 2016), and this finding from 2014 confirms that, under certain circumstances, established parties do in fact attach salience to EU issues (see also Adam et al. 2017). But which factors actually drive the communication strategies of the different party groups?

[Tables 1 about here]

Tables $2 \mathrm{a}$ to $4 \mathrm{~b}$ present the findings from linear mixed-effects analyses of the factors that increase a party's EU issue salience, that is the share of press releases in which a party mentioned the EU at least twice (category 1), or even assigned distinct EU scopes to its press releases (category 2). The first model (Tables $2 \mathrm{a}$ and $2 \mathrm{~b}$ ) estimates the driving factors for all parties and includes a dummy variable for governing parties (party type) to test whether their communication is significantly different from all opposition parties. Model 2 (Tables 3a and 3b) analyzes the communication of all established parties (i.e. governing parties and established opposition parties), controlling for a systematic difference between governing and established opposition parties by including a dummy variable for governing parties (party type). Model 3 (Tables $4 \mathrm{a}$ and $4 \mathrm{~b}$ ) includes again all parties and finally tests for a difference between established (governing and opposition) and challenger parties by means of another dummy variable for established parties. To test our specific hypotheses, the models are first estimated without interaction terms to assess the direct effect of each variable independently (upper part of each table) and then the interactions - between strength of leadership and inner party dissent (H2a), strength of leadership and national election cycle (H2b), and between party's and citizens' EU-support (H3) - are included (middle part of each table). Finally, each model is re-estimated separately, including the interactions among the predictor variables and party groups (lower part of each table). 
The findings for the direct effects of the variable party type displayed in the upper parts of Tables 2 to 4 first confirm the results from our descriptive analysis. No significant differences can be found between challenger and established parties (be they in government or in opposition), neither with regards to just mentioning EU issues (cat. 1; all $p_{\text {party type n.s.) }}$ nor regarding choosing distinct EU scopes in their communication (cat. 2; all $p_{\text {party type }}$ n.s.). Thus, our preliminary answer to research question 1, that in 2014 challenger parties did not attach greater salience to EU issues than established or especially governing parties, is also confirmed in this multivariate model.

[Tables $2 \mathrm{a}$ and $2 \mathrm{~b}$ about here]

[Tables $3 \mathrm{a}$ and $3 \mathrm{~b}$ about here]

[Tables $4 \mathrm{a}$ and $4 \mathrm{~b}$ about here]

Moving on to the explanatory factors derived from the selective emphasis model, the results first confirm the relevance of inner party dissent regarding EU integration to parties' communication strategies. In all basic models (upper parts of the tables, i.e. excluding the interaction terms), internal dissent decreases the probability that parties will mobilize on EU matters (all $p_{\text {inner party dissent }}<.10$ ) with only one exception: for established parties, inner dissent does not reduce the likelihood of choosing a distinct EU scope (cat. 2: Coef $_{\text {model2 }}$ n.s.). However, overall this finding supports hypothesis 1 , and no significant variation is found between party groups (see interaction terms with party types in the lower part of tables).

The subsequent models including further all three two-way interactions show that the interaction between inner party dissent regarding the EU and strength of party leadership, measured through past electoral performance (SOL, middle part of tables), has a positive 
effect on the EU mobilization for all parties (models1 and $3 p_{S O L} x$ dissent $\left.<.10\right) .{ }^{6}$ This means if a party is unsuccessful on the national level, its weak leadership - i.e., one with a prior weak electoral performance - will only risk talking about the EU and/or distinct EU policies in an EP campaign if inner party dissent regarding the EU is low. As inner party conflict increases, they start to avoid the topic in press releases (see also margin plots for all significant interaction terms in the Web appendix). By contrast, EU salience hardly varies based on inner party dissent for parties with a strong leadership. However, the between-party-type comparisons (lower part of tables, including in addition each three-way interaction separately) indicate that successful leaderships of governing parties facing strong internal divisions are less likely to mention the EU or to even put specific EU issues on the agenda when compared to (established) opposition parties (cat. 1: Coef $_{\text {model } 2}=-.360 * * *$; cat. 2: Coef $f_{\text {model }}=-.195^{*}$, Coef $\left._{\text {model }}=-.656^{* * *}\right){ }^{7}$ The margin plots in Figure 1 and Figure 2 illustrate the findings for governing parties also in the sense of hypothesis $2 \mathrm{a}$ : Governing parties with internal division on EU issues and a weak leadership are more likely to put EU issues on their agendas than their counterparts with a strong leadership. This effect is the strongest to emerge in any of our models, and is fully in line with the muffling thesis. However, hypothesis $2 \mathrm{a}$ is only partially supported as this effect is not found for all established parties, but only for governing parties as compared to (established) opposition parties.

[Figure 1 about here]

[Figure 2 about here]

\footnotetext{
${ }^{6}$ The effects of the interaction terms are the same when included one by one.

${ }^{7}$ The interaction term is not significant for model 2 with the EU issues mentioned at least twice (cat. 1, see Web appendix).
} 
Testing for the next determinant defined in the selective emphasis model, the timing within the election cycle (i.e. closeness to the next national election following the 2014 EPE, respectively distance from midterm) in interaction with strength of party leadership (again middle and lower parts of tables), we do not find evidence for the expected effect: There is no evidence that parties with weak leadership resulting from previous electoral let-downs are more likely to put EU issues on the agenda than those with strong leaders who are riding the wave of a previous success if the next elections are close. Therefore, hypothesis $2 \mathrm{~b}$ must be rejected.

For the last predictor stemming from the selective emphasis approach, i.e. congruence between citizens' and the party's EU positions (also middle parts of tables), we expected that all parties would be more likely to exploit EU issues if they would have citizens' support. However, this mechanism is only found for established parties (governing and opposition alike; Model 2). The findings indicate that established parties are indeed more likely to mention the EU or even choose a distinct EU scope if they can be sure that the general public supports their position (cat. 1: Coef model2 $=.091^{* *}$; cat. 2: Coef $f_{\text {model }}=.128^{*}$ ). This result partly supports hypothesis 3 .

Finally turning to the predictors of the co-orientation model, hypothesis $4 \mathrm{a}$ assumes the salience of EU issues on governing parties' agendas to be similar to the agendas of opposition parties. In this regard, we first find that co-orientation with (other) opposition parties only matters in terms of the choice of specific EU scopes (cat. 2: all $p_{E U \text {-emphasis opp. }}$ parties $<.10$; upper parts of tables): That is, the more often opposition parties use specific EU scopes, the higher the probability that all other parties will do so, too. No differences between party types are found (all $p_{\text {interactions with party types }}$ n.s.; lower parts of tables). However, as the effect was detected for all party types, hypothesis 4a is supported regarding the choice of EUscope for governing parties as well. 
On the other hand, hypothesis $4 \mathrm{~b}$ claims that the salience of EU issues on challenger parties' agendas will be independent from the EU salience on the agendas of governing parties (Models 1 and 3). Indeed, we find that the EU-salience in governing parties' campaigns has only a marginal positive effect on all other parties' likelihood to also mention the EU (cat. 1: Coef $_{\text {modell }}=.031^{+}$; Coef $f_{\text {model } 2}=.030^{+}$; upper parts of tables) while no effect is

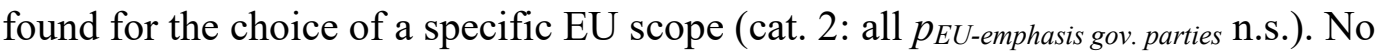
differences are found between established and challenger parties (Model 3: all $p_{\text {interactions with }}$ party types n.s.; lower parts of tables). This means that challenger parties as well as all other parties have some tendency to also mention issues that government parties put on their agendas, but their issue scopes are independent from government parties. In sum, we would see hypothesis $4 \mathrm{~b}$ as partially supported.

To check for the robustness of the results we re-estimated all models using logistic regressions and excluding one party or country at a time. Overall, the findings are quite robust (see Web appendix). The findings from the logistic regression provide empirical support for the relevance of inner party dissent (H1). This is also the case for the interaction between inner party dissent regarding the EU, strength of party leadership measured through past electoral performance and party type (H2a), at least when EU issue scope (cat. 2) but not if just EU mentioning (cat. 1) is used as dependent variable. A closer inspection of the results excluding single countries and parties reveals that the PASOK, the social democrats in Greece, (Model 1, cat. 2 and Model 2, cat. 1 and 2) and to a lower extent also the liberal NEOS and the right-wing populist BZÖ in Austria are outliers (Mod. 1, cat. 2). In line with the results from the linear mixed-effects models, we find no empirical evidence in the logistic regression for the interaction between the timing within the election cycle and the strength of party leaders $(\mathrm{H} 2 \mathrm{~b})$. The logistic regression provides no empirical support for the selective emphasis model testing the congruence between citizens' and party's EU position (H3). 
Looking at the results by country and party shows that the Socialist Party in Portugal (interaction coefficient is more than six times higher) and the Democratic Movement in France (n.s.) are odd cases in both models using EU mentioning and distinct EU scope as dependent variable. Finally, turning to the co-orientation models, only the effect of the EU salience in opposition parties' campaigns ( $\mathrm{H} 4 \mathrm{~b})$ can be confirmed by the findings from the logistic regression, but not those of governing parties' campaigns (H4a).

\section{Summary and Discussion}

Our analysis shows that, in the context of the 2014 EP elections, established and especially governing parties no longer silenced EU issues to the same extent that they had in the past. This finding aligns well with a trend that emerged in the 2009 EP elections (Adam and Maier 2016). While there are significant variations across the seven countries, on average, governing parties referred to EU issues in $35 \%$ of their press releases, mentioning the EU at least twice. Also, at the aggregate level, specific EU scopes were significantly more likely to be featured in the press releases from governing parties than from established opposition and challenger parties. However, this general pattern was not observed in the Netherlands, France, or Germany, where challenger parties were still most likely put the EU on their campaign agendas. Further, the variation in salience of EU issues between countries and party groups was quite large. These findings beg question of which factors encourage or dissuade parties to put EU topics on the agenda.

Indicators derived from the selective emphasis approach, as well as from the coorientation thesis, turned out to be valuable in terms of explaining parties' communication strategies in our integrated models. Stemming from the selective emphasis approach a) inner party dissent about European integration, b) the interaction between this factor and the 
strength of party leadership resulting from electoral success on the national level, as well as c) (to a lower extent) the congruence between citizens' and the party's EU positions systematically influence the strategic communication behaviour at least for certain party types: Very much in line with the literature (e.g. Adam et al. 2017; Hobolt and De Vries 2015), parties with high internal dissent on EU integration in general try to avoid EU issues regardless of the party type. In addition, if a party is not successful on the national level, its weak leadership will only dare talking about the EU or specific EU policies in an EP campaign if internal dissent is low. However, the comparison between party types shows that successful leaders of governing parties are still the most likely to muffle the issue if their party is internally divided (Parsons and Weber 2011). No effect was found, however, for the interaction between strength of leadership and timing of the EP elections within the national election cycle. Instead established parties (government and opposition alike) also showed responsiveness to public opinion: If their positions on EU matters were supported by the citizens, they were more likely to put these issues on their campaign agendas than if the positions were incongruent.

Looking at factors derived from the co-orientation model, orientation towards the communication behaviour of opposition parties appears to have a systematic effect only on choosing a specific EU scope. The more often opposition parties use specific EU foci, the higher the probability is that all other parties do so, too. On the contrary, if governing parties try to mobilize on EU matters this has only marginal effects on all other parties in the sense that they also 'symbolically' mention the EU. The decision to more substantially engage in the issue by also using specific issue scopes is for all party types independent from the agendas of governing parties.

The robustness of our findings has been checked thoroughly. Nonetheless, there are outliners on party- and country-level which are plausible given the broad variance described 
above (see Web appendix). However, in order to account for the effect of outliers, further analyses should include a broad data base of countries and parties. The fact that some effects turned out differently than expected based on existing literature might be due to actual changes in parties' communication strategies. However, it could also be due to the more advanced simultaneous testing made possible by the integrated model. Thus, the combination of predictors from the selective emphasis and co-orientation approaches as well as the interactions described in the literature seem to be a promising way to analyse the development of parties' strategic communication.

Thus, the results suggest that the communication behaviour of established parties during EP campaigns has changed significantly, building on a trend that has first become visible in 2009: Governing parties appear to no longer avoid discussion of EU matters in general. Nevertheless, even if the general picture looks promising, variation among countries and parties is high, and for many parties, it remains true that EP campaigns are still largely domesticized (Boomgaarden and De Vreese 2016). Thus these campaigns fail to provide citizens with the information necessary to 'decide issues' (Schumpeter 2003: 250), as argued earlier. Future studies should, therefore, aim to take into account an even broader sample of EU countries in order to adequately assess the development of the European public sphere which varies strongly between the countries.

Further, our analysis has two obvious shortcomings that should also be taken into account in future research: First, while we took into account EU salience of the parties' messages, we did not look at their valence. Second, due to lacking data from earlier EP campaigns, it was not possible to draw causal conclusions. This would be highly valuable in future research, and particularly in terms of the co-orientation thesis. 


\section{References}

Adam, Silke, and Michaela Maier (2011). 'National parties as politicizers of EU integration? Party campaign communication in the run-up to the 2009 European Parliament election', European Union Politics, 12:3, 431-53.

Adam, Silke, and Michaela Maier (2016). 'Campaigning on or downplaying European Union Integration? Ex-plaining the salience parties attach to EU matters in European Parliamentary election campaigns', in Wouter Van der Brug and Claes H. de Vreese, (eds.), Unintended consequences of EU Parliamentary elections. Oxford: Oxford University Press, 148-70

Adam, Silke, and Michaela Maier (2018). Data from: The role of national parties for the politicization of EU integration [Dataset]. Retrieved from https://forsbase.unil.ch/project/study-public-overview/11960/0/

Adam, Silke, Eva-Maria Antl-Wittenberg, Beatrice Eugster, Melanie Leidecker-Sandmann, Michaela Maier, Franzisca Schmidt (2017) 'Strategies of pro-European parties in the face of a Eurosceptic challenge', European Union Politics, 18:2, 260-82.

Adam, Silke, Beatrice Eugster, Eva Antl-Wittenberg, Rachid Azrout, Judith Möller, Claes de Vreese, Michaela Maier, and Sylvia Kritzinger (2019). 'News media’s position-taking regarding the European Union: The synchronization of mass media's reporting and commentating in the 2014 European Parliament elections', Journal of European Public Policy, 26:1, 44-62.

Ansolabehere, Stephen, and Shanto Iyengar (1994). 'Riding the Wave and Claiming Ownership Over Issues: The Joint Effects of Advertising and News Coverage in Campaigns’ Public Opinion Quarterly 58:3, 335-357.

Boomgaarden, Hajo G., and Claes H. De Vreese (2016). 'Do European elections create a European public sphere?', in Wouter Van der Brug, and Claes H. De Vreese (eds.), 
(Un)intended Consequences of EU Parliamentary Elections. Oxford: Oxford University Press: 19-35.

Braun, Daniela, Swen Hutter, and Alena Kerscher (2016). 'What type of Europe? The salience of polity and policy issues in European Parliament elections', European Union Politics, 17:4, 570-592.

Budge, Ian (2015). 'Issue Emphases, Saliency Theory and Issue Ownership: A Historical and Conceptual Analysis’ West European Politics 38:4, 761-777.

Budge, Ian, and Dennis Farlie (1983). 'Party competition - selective emphasis or direct confrontation? An alternative view with data', in Hans Daalder and Peter Mair (eds.), Western European Party Systems: Continuity \& Change. Los Angeles, CA: Sage Publications Ltd: 267-305.

Damore, David F. (2004). 'The Dynamics of Issue Ownership in Presidential Campaigns, Political Research Quarterly, 57:3, 391-397.

De Sio, Lorenzo, and Till Weber (2020). 'Issue Yield, Campaign Communication, and Electoral Performance: A Six-Country Comparative Analysis', West European Politics, 43:3, 720-45.

De Vreese, Claes H. (2009). 'Second-Rate Election Campaigning? An Analysis of Campaign Styles in European Parliamentary Elections', Journal of Political Marketing, 8:1, 719.

De Vreese, Claes H., Susan A. Banducci, Holli A. Semetko, and Hajo G. Boomgaarden (2006). 'The News Coverage of the 2004 European Parliamentary Election Campaign in 25 Countries', European Union Politics, 7:4, 477-504.

De Vries, Catherine E., and Sara B. Hobolt (2012). 'When dimensions collide: The electoral success of issue entrepreneurs', European Union Politics, 13:2, 246-268. 
Dolezal, Martin, Laurenz Ennser-Jedenastik, Wolfgang C. Müller, and Anna Katharina Winkler (2014). 'How Parties Compete for Votes: A Test of Saliency Theory', European Journal of Political Research, 53:1, 57-76.

Döring, Holger, and Philip Manow (2016). Data from: Parliaments and governments database (ParlGov): Information on parties, elections and cabinets in modern democracies. Development version [Dataset]. Retrieved from: http://www.parlgov.org/explore/deu/cabinet/.

European Commission (2015). Data from: Eurobarometer 81.4 (2014) [Dataset]. Retrieved from: https://www.gesis.org/index.php?id=10324\&tx.

European Parliament (2014). 'The 2014 European Elections: This Time It's Different' (1102-2014). Available online at: https://www.europarl.europa.eu/sides/getDoc.do?type= $\underline{\text { IM-PRESS\&reference }=20140210 \mathrm{BKG} 35568 \& \text { format }=\mathrm{XML} \& \text { language }=\mathrm{EN}}$ [accessed 25/2/2020]

Franklin, Mark N., and Julie Hassing Nielsen (2017). 'Conclusions: The 2014 EP Elections as a Lens on Euroscepticism', in Julie Hassing Nielsen and Mark N. Franklin (eds), The Eurosceptic 2014 European Parliament Elections: Second Order or Second Rate?, London: Palgrave Macmillan UK: 239-53.

Geys, Benny (2012). 'Success and failure in electoral competition: Selective issue emphasis under incomplete issue ownership', Electoral Studies, 31:2, 406-412.

Green-Pedersen, Christoffer, and Peter B. Mortensen (2010). 'Who sets the agenda and who responds to it in the Danish parliament? A new model of issue competition and agenda-setting'. European Journal of Political Research, 49:2, 257-281.

Hayes, Danny (2008). 'Party Reputations, Journalistic Expectations: How Issue Ownership Influences Election News', Political Communication, 25:4, 377-400. 
Hobolt, Sara B., and Catherine E. De Vries (2015). 'Issue Entrepreneurship and Multiparty Competition', Comparative Political Studies, 48:9, 1159-1185.

Hobolt, Sara B., and Catherine E. de Vries (2016). 'Turning against the Union? The Impact of the Crisis on the Eurosceptic Vote in the 2014 European Parliament Elections', Electoral Studies, 44, 504-14.

Hoeglinger, Dominic (2016). 'The politicisation of European integration in domestic election campaigns', West European Politics, 39:1, 44-63.

Holian, David B. (2004). 'He’s Stealing My Issues! Clinton's Crime Rhetoric and the Dynamics of Issue Ownership', Political Behavior, 26:2, 95-124.

Hooghe, Liesbet, and Gary Marks (2009). 'A Postfunctionalist Theory of European Integration: From Permissive Consensus to Constraining Dissensus', British Journal of Political Science, 39:1, 1-23.

Hopmann, David N., Christian Elmelund-Præstekær, Erik Albæk, Rens Vliegenthart, and Claes H. De Vreese (2012). 'Party media agenda-setting: How parties influence election news coverage', Party Politics, 18:2, 173-191.

Jalali, Carlos and Tiago Silva (2011). 'Everyone ignores Europe? Party campaigns and media coverage in the 2009 European Parliament elections' in Michaela Maier, Jesper Strömbäck and Lynda Lee Kaid (eds.), Political Communcation in European Parliamentary Elections. Farnham: Ashgate, 111-28.

Koopmans, Ruud (2002). Codebook for the analysis of political mobilisation and communication in European public spheres. Available at: https://europub.wzb.eu/Data/Codebooks\%20questionnaires/D2-1-claimscodebook.pdf (accessed 23.08.2019) 
Kriesi, Hanspeter, Edgar Grande, Martin Dolezal, Marc Helbling, Dominc Hoeglinger, Swen Hutter, and Bruno Wüest (2012). Political Conflict in Western Europe. Cambridge: Cambridge University Press.

Lefevere, Jonas, Anke Tresch, and Stefaan Walgrave (2015). 'Associative Issue Ownership as a Determinant of Voters' Campaign Attention', West European Politics, 38:4, 888908.

Leidecker-Sandmann, Melanie, Eva Antl-Wittenberg, Silke Adam and Michaela Maier (2016). 'Struggle for eco-nomic issue ownership? Political parties' strategic communication in times of the European financial crisis', unpublished paper, University of Landau.

Lindberg, Leon N., and Stuart A. Scheingold (1970). Europe's would-be polity: Patterns of change in the European Community. Englewood Cliffs, NJ: Prentice-Hall.

Machill, Marcel, Markus Beiler, and Corinna Fischer (2006). 'Europe-Topics in Europe's Media: The Debate about the European Public Sphere: A Meta-Analysis of Media Content Analyses', European Journal of Communication, 21:1, 57-88.

Maier, Michaela and Jürgen Maier (2008). 'News coverage of EU Parliamentary elections' in Jesper Strömbäck and Lynda Lee Kaid (eds.), The handbook of election news coverage around the world. New York: Routledge, 403-20.

Mair, Peter (1997). Party system change: Approaches and interpretations. Oxford: Clarendon Press.

Marsh, Michael (1998). 'Testing the Second-Order Election Model after Four European Elections', British Journal of Political Science, 28:4, 591-607.

Meijers, Maurits, and Christian Rauh (2016). 'Has Eurosceptic Mobilization Become More Contagious? Comparing the 2009 and 2014 EP Election Campaigns in The Netherlands and France', Politics and Governance, 4:1, 83-103. 
Netjes, Catherine E., and Hamen A. Binnema (2007). The salience of the European integration issue: Three data sources compared, Electoral Studies, 26::1,: 39-49.

Parsons, Craig, and Till Weber (2011). 'Cross-Cutting Issues and Party Strategy in the European Union', Comparative Political Studies, 44:4, 383-411.

Petithomme, Mathieu (2012). 'Second-Order Elections, but also 'Low-Cost' Campaigns? National Parties and Campaign Spending in European Elections: A Comparative Analysis', Perspectives on European Politics and Society, 13:2, 149-168.

Petrocik, John R. (1996). 'Issue Ownership in Presidential Elections, with a 1980 Case Study', American Journal of Political Science, 40:3, 825-850.

Polk, Jonathan et al. (2017). 'Explaining the salience of anti-elitism and reducing political corruption for political parties in Europe with the 2014 Chapel Hill Expert Survey data', Research \& Politics 4 (1): 1-9.

Reif, Karlheinz, and Hermann Schmitt (1980). ,Nine second-order national elections: A conceptual framework for the analysis of European election results', European Journal of Political Research, 8:1, 3-44.

Reif, Karlheinz, Hermann Schmitt, and Pippa Norris (1997). 'Second-order elections', European Journal of Political Research, 31:1-2, 109-124.

Rooduijn, Matthijs (2015). 'The Rise of the Populist Radical Right in Western Europe', European View, 14:1, 3-11.

Schmitt, Hermann, and Eftichia Teperoglou (2015). 'The 2014 European Parliament Elections in Southern Europe: Second-Order or Critical Elections?', South European Society and Politics, 20:3, 287-309.

Schmitt, Hermann, and Ilke Toygür (2016). 'European Parliament Elections of May 2014: Driven by National Politics or EU Policy Making?', Politics and Governance, 4:1, $167-81$. 
Schuck, Andreas R.T., and Claes H. De Vreese (2011). 'Finding Europe: Mapping and explaining antecedents of "Europeanness" in news about the 2009 European Parliamentary Elections', Studies in Communication | Media, 0:2, 265-294.

Schumpeter, Joseph A., and Richard Swedberg (2003) Capitalism, Socialism, and Democracy. New York, NY: Routledge.

Sides, John (2006). 'The Origins of Campaign Agendas', British Journal of Political Science, $36: 3,407-36$.

Sigelman, Lee, and Emmett H. Buell (2004). ‘Avoidance or Engagement? Issue Convergence in U.S. Presidential Campaigns, 1960-2000', American Journal of Political Science, $48: 4,650-61$.

Steenbergen, Marco R., and David J. Scott (2004). 'Contesting Europe? The salience of European integration as a party issue', in Gary Marks and Marco R. Steenbergen (eds.), European Integration and Political Conflict. Cambridge: Cambridge University Press, 165-192.

Tresch, Anke, Jonas Lefevere, and Stefaan Walgrave (2015). “'Steal me if you can!” The impact of campaign messages on associative issue ownership', Party Politics, 21:2, $198-208$.

Van de Wardt, Marc, Catherine E. De Vries, and Sara B. Hobolt (2014). 'Exploiting the Cracks: Wedge Issues in Multiparty Competition', The Journal of Politics, 76:4, 986999.

Van der Eijk, Cees, and Mark N. Franklin (2004). 'Potential for contestation on European matters at national elections in Europe', in Gary Marks and Marco R. Steenbergen (eds.), European Integration and Political Conflict. Cambridge: Cambridge University Press: 32-50. 
Wagner, Markus, and Thomas M. Meyer (2014). 'Which Issues do Parties Emphasise?

Salience Strategies and Party Organisation in Multiparty Systems', West European Politics, 37:5, 1019-1045.

Walgrave, Stefaan, Jonas Lefevere, and Michiel Nuytemans (2009). 'Issue Ownership Stability and Change: How Political Parties Claim and Maintain Issues Through Media Appearances', Political Communication, 26:2, 153-172.

Ware, Alan (1996). Political Parties and Party Systems. Oxford: Oxford University Press. 
Table 1: Salience of EU-issues in parties' 2014 EP campaigns (\% of press releases) ${ }^{\mathrm{a}}$

\begin{tabular}{|c|c|c|c|c|}
\hline & $\begin{array}{c}\text { Governing } \\
\text { Parties }\end{array}$ & $\begin{array}{l}\text { Established } \\
\text { Opposition }\end{array}$ & $\begin{array}{c}\text { Challenger } \\
\text { Parties }\end{array}$ & Total \\
\hline \multicolumn{5}{|l|}{ Austria } \\
\hline EU only mentioned & 5.6 & 4.5 & 4.7 & 5.1 \\
\hline EU mentioned and EU-scope & $35.1 * *$ & 23.2 & 27.2 & 30.8 \\
\hline N Press Releases (N Parties) & $1426(2)$ & $491(1)$ & $687(3)$ & $2604(6)$ \\
\hline \multicolumn{5}{|l|}{ France } \\
\hline EU only mentioned & 4.6 & 12.2 & 13.9 & 11.4 \\
\hline EU mentioned and EU-scope & $10.1 * *$ & 16.7 & 19.9 & 16.6 \\
\hline $\mathrm{N}$ & $109(1)$ & $329(3)$ & $109(2)$ & $639(6)$ \\
\hline \multicolumn{5}{|l|}{ Germany } \\
\hline EU only mentioned & 5.2 & 3.8 & 4.0 & 4.4 \\
\hline EU mentioned and EU-scope & $18.3^{* *}$ & 17.4 & 20.5 & 18.6 \\
\hline $\mathrm{N}$ & $558(2)$ & $397(2)$ & $351(2)$ & $1306(6)$ \\
\hline \multicolumn{5}{|l|}{ Greece } \\
\hline EU only mentioned & 5.0 & - & 4.1 & 4.2 \\
\hline EU mentioned and EU-scope & $31.2^{* *}$ & - & 19.5 & 21.2 \\
\hline $\mathrm{N}$ & $301(2)$ & $\begin{array}{c}- \\
(0)\end{array}$ & $1733(7)$ & $2034(9)$ \\
\hline \multicolumn{5}{|l|}{ Netherlands } \\
\hline EU only mentioned & 2.3 & 3.4 & 7.6 & 5.3 \\
\hline EU mentioned and EU-scope & $19.5^{* * *}$ & 26.4 & 30.9 & 27.0 \\
\hline $\mathrm{N}$ & $128(2)$ & $148(2)$ & $275(5)$ & $551(9)$ \\
\hline \multicolumn{5}{|l|}{ Portugal } \\
\hline EU only mentioned & 3.2 & 3.1 & 8.8 & 5.5 \\
\hline EU mentioned and EU-scope & $57.6^{* * *}$ & 38.6 & 38.6 & 42.0 \\
\hline $\mathrm{N}$ & $125(1)$ & $290(1)$ & $295(2)$ & $710(4)$ \\
\hline \multicolumn{5}{|l|}{ United Kingdom } \\
\hline EU only mentioned & 3.5 & 2.8 & 4.8 & 4.0 \\
\hline EU mentioned and EU-scope & $26.3^{* * *}$ & 4.4 & 15.6 & 13.8 \\
\hline $\mathrm{N}$ & $198(2)$ & $390(1)$ & $668(3)$ & $1256(6)$ \\
\hline \multicolumn{5}{|l|}{ Total } \\
\hline EU only mentioned & 5.0 & 5.0 & 5.3 & 5.2 \\
\hline EU mentioned and EU-scope & $30.1 * *$ & 19.9 & 22.3 & 24.2 \\
\hline Total EU-references & $35.1^{* * *}$ & 24.8 & 27.6 & 29.4 \\
\hline$\overline{\mathrm{N}}$ & $2845(12)$ & $2045(10)$ & $4210(24)$ & $9100(46)$ \\
\hline
\end{tabular}

Missing percentages: no EU-reference.

Notes: Significant differences between party groups: $* * * \mathrm{p}<0.001 ; * * \mathrm{p}<0.01$.

France: New Anti-capitalist Party (NPA) is not included in the study since information on key structural variables for the regression models is lacking. 
Table 2a: Model 1, Established Governing Parties vs. Opposition (EU mentioned min. twice)

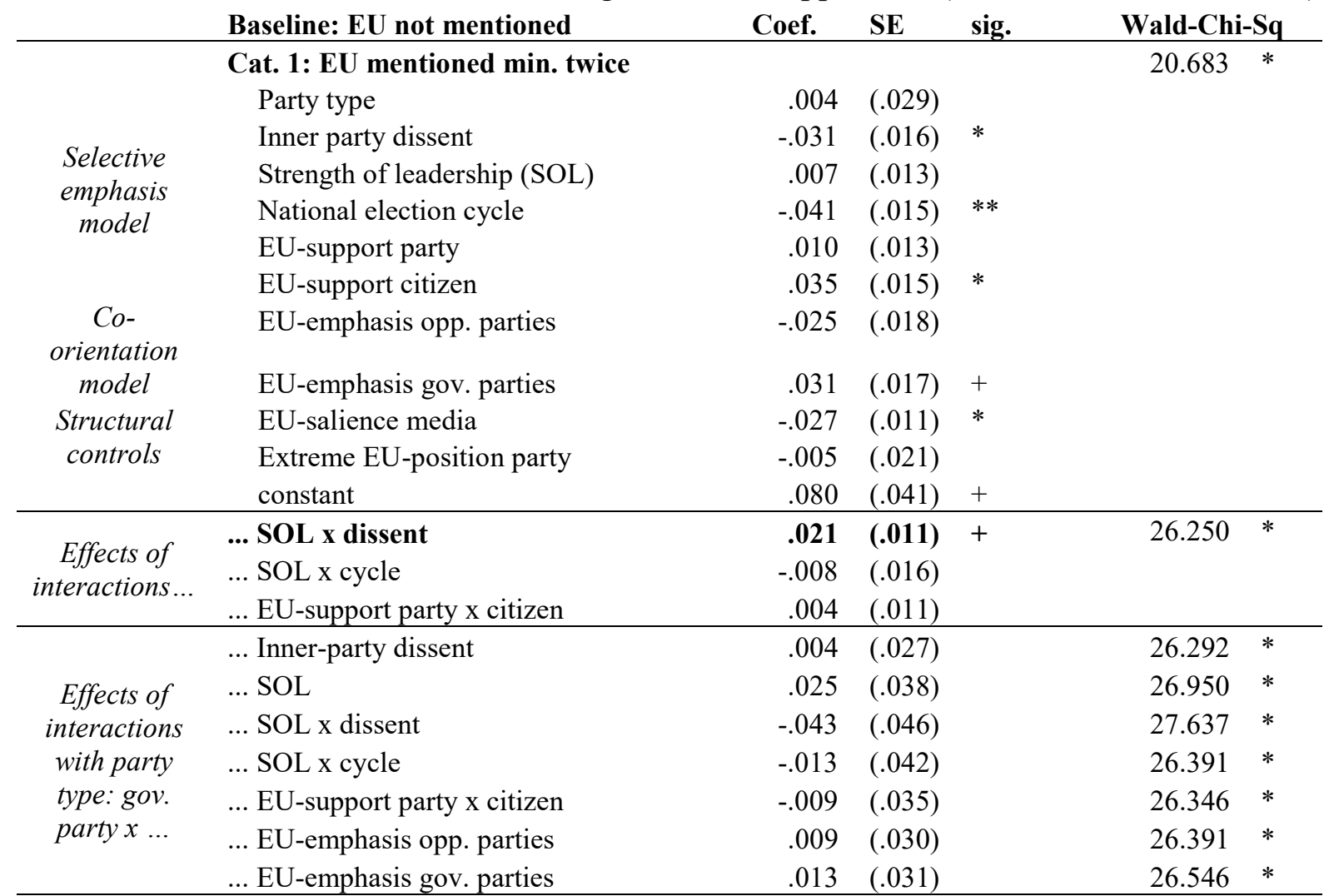

Note: Source: Own data, Linear mixed-effects models, $\mathrm{N}=46$ parties in 7 countries, displayed are coefficients and standard errors in parenthesis; levels of significance: ${ }^{+} \mathrm{p}<.10 ;{ }^{*} \mathrm{p}<.05 ; * * \mathrm{p}<.01 ; * * * \mathrm{p}<.001$. Dependent variable ranges from 0 to $1(100 \%)$. Bold fonts mark significant interaction effects for which margin plots are provided in the Web appendix 
Table 2b: Model 1, Established Governing Parties vs. Opposition (Distinct EU-scope)

\begin{tabular}{|c|c|c|c|c|c|c|}
\hline & Baseline: EU not mentioned & Coef. & SE & sig. & \multicolumn{2}{|c|}{ Wald-Chi-Sq. } \\
\hline & Cat. 2: Distinct EU-scope & & & & 24.279 & $* *$ \\
\hline \multirow{6}{*}{$\begin{array}{c}\text { Selective } \\
\text { emphasis } \\
\text { model }\end{array}$} & Party type & .014 & $(.051)$ & & & \\
\hline & Inner party dissent & -.074 & $(.028)$ & $* *$ & & \\
\hline & Strength of leadership (SOL) & -.024 & $(.024)$ & & & \\
\hline & National election cycle & .015 & $(.027)$ & & & \\
\hline & EU-support party & .016 & $(.024)$ & & & \\
\hline & EU-support citizen & -.030 & $(.027)$ & & & \\
\hline \multirow{5}{*}{$\begin{array}{l}\text { Co- } \\
\text { orientation } \\
\text { model } \\
\text { Structural } \\
\text { controls }\end{array}$} & EU-emphasis opp. parties & .079 & $(.032)$ & * & & \\
\hline & EU-emphasis gov. parties & -.027 & $(.031)$ & & & \\
\hline & EU-salience media & -.021 & $(.020)$ & & & \\
\hline & Extreme EU-position party & -.035 & $(.037)$ & & & \\
\hline & constant & .330 & $(.074)$ & $* * *$ & & \\
\hline \multirow{3}{*}{$\begin{array}{c}\text { Effects of } \\
\text { interactions... }\end{array}$} & ... SOL $x$ dissent & .046 & (.019) & $*$ & 33.033 & $* *$ \\
\hline & ... SOL x cycle & -.011 & $(.028)$ & & & \\
\hline & ... EU-support party $\mathrm{x}$ citizen & .010 & $(.019)$ & & & \\
\hline \multirow{7}{*}{$\begin{array}{c}\text { Effects of } \\
\text { interactions } \\
\text { with party } \\
\text { type: gov. } \\
\text { party } x . . .\end{array}$} & ... Inner-party dissent & .000 & $(.048)$ & & 33.033 & $* *$ \\
\hline & ... SOL & .134 & $(.064)$ & $*$ & 40.580 & $* * *$ \\
\hline & ... SOL $x$ dissent & -.195 & $(.077)$ & $*$ & 43.985 & $* * *$ \\
\hline & ... SOL x cycle & -.117 & $(.072)$ & & 37.550 & $* * *$ \\
\hline & ... EU-support party $x$ citizen & -.017 & $(.062)$ & & 33.164 & $* *$ \\
\hline & ... EU-emphasis opp. parties & .016 & $(.053)$ & & 33.180 & $* *$ \\
\hline & ... EU-emphasis gov. parties & .017 & $(.054)$ & & 33.206 & $* *$ \\
\hline
\end{tabular}

Note: Source: Own data, Linear mixed-effects models, $\mathrm{N}=46$ parties in 7 countries, displayed are coefficients and standard errors in parenthesis; levels of significance: ${ }^{+} \mathrm{p}<.10 ;{ }^{*} \mathrm{p}<.05 ; * * \mathrm{p}<.01 ; * * * \mathrm{p}<.001$. Dependent variable ranges from 0 to $1(100 \%)$.

Bold fonts mark significant interaction effects for which margin plots are provided in the Web appendix. 
Table 3a: Model 2, Established Governing Parties vs. Established Opposition (EU mentioned min. twice)

\begin{tabular}{|c|c|c|c|c|c|c|}
\hline & Baseline: EU not mentioned & Coef. & SE & sig. & Wald-Ch & $-S q$ \\
\hline & Cat. 1: EU mentioned min. twice & & & & 18.461 & * \\
\hline & Party type & .052 & $(.043)$ & & & \\
\hline & Inner party dissent & -.058 & $(.030)$ & + & & \\
\hline Delectlve & Strength of leadership (SOL) & -.027 & $(.023)$ & & & \\
\hline model & National election cycle & -.047 & $(.020)$ & $*$ & & \\
\hline & EU-support party & -.023 & $(.035)$ & & & \\
\hline & EU-support citizen & .044 & $(.021)$ & $*$ & & \\
\hline Co- & EU-emphasis opp. parties & -.022 & $(.021)$ & & & \\
\hline model & EU-emphasis gov. parties & .011 & $(.022)$ & & & \\
\hline Structural & EU-salience media & -.053 & $(.023)$ & * & & \\
\hline controls & Extreme EU-position party & .003 & (.059) & & & \\
\hline & constant & .027 & $(.115)$ & & & \\
\hline Fffects of & $\ldots$ SOL $x$ dissent & -.018 & $(.025)$ & & 33.600 & ** \\
\hline interactions & ... SOL $x$ cycle & -.016 & $(.021)$ & & & \\
\hline & ... EU-support party $x$ citizen & .091 & $(.034)$ & $* *$ & & \\
\hline & ... Inner-party dissent & .145 & (.075) & + & 42.729 & $* * *$ \\
\hline Effects of & $\ldots$ SOL & .292 & (.052) & $* * *$ & 110.939 & $* * *$ \\
\hline interactions & ... SOL x dissent & -.360 & (.075) & $* * *$ & 90.995 & $* * *$ \\
\hline with party & ... SOL $x$ cycle & -.063 & (.046) & & 38.349 & $* * *$ \\
\hline type: gov. & ... EU-support party $\mathrm{x}$ citizen & -.057 & $(.050)$ & & 36.780 & $* * *$ \\
\hline $\operatorname{party} x \ldots$ & ... EU-emphasis opp. parties & .020 & $(.045)$ & & 34.097 & ** \\
\hline & EU-emphasis gov. parties & -.028 & $(.061)$ & & 34.110 & ** \\
\hline
\end{tabular}

Note: Source: Own data, Linear mixed-effects models, $\mathrm{N}=23$ parties in 7 countries, displayed are coefficients and standard errors in parenthesis; levels of significance: ${ }^{+} \mathrm{p}<.10 ;{ }^{*} \mathrm{p}<.05 ; * * \mathrm{p}<.01 ; * * * \mathrm{p}<.001$. Dependent variable ranges from 0 to $1(100 \%)$

Bold fonts mark significant interaction effects for which margin plots are provided in the Web appendix. 
Table 3b: Model 2, Established Governing Parties vs. Established Opposition (Distinct EUscope)

\begin{tabular}{|c|c|c|c|c|c|c|}
\hline & Baseline: EU not mentioned & Coef. & SE & sig. & Wald-Chi & \\
\hline & Cat. 2: Distinct EU-scope & & & & 25.672 & $* *$ \\
\hline & Party type & .089 & $(.072)$ & & & \\
\hline & Inner party dissent & -.081 & $(.050)$ & & & \\
\hline Selective & Strength of leadership (SOL) & -.030 & $(.038)$ & & & \\
\hline model & National election cycle & -.021 & $(.033)$ & & & \\
\hline & EU-support party & -.011 & $(.058)$ & & & \\
\hline & EU-support citizen & .002 & $(.034)$ & & & \\
\hline $\mathrm{Co}-$ & EU-emphasis opp. parties & .069 & $(.036)$ & + & & \\
\hline $\begin{array}{c}\text { orientation } \\
\text { model }\end{array}$ & EU-emphasis gov. parties & -.010 & $(.037)$ & & & \\
\hline Structural & EU-salience media & -.050 & $(.039)$ & & & \\
\hline controls & Extreme EU-position party & .070 & $(.098)$ & & & \\
\hline & constant & .060 & $(.192)$ & & & \\
\hline Fffects of & ... SOL $x$ dissent & -.023 & $(.044)$ & & 37.567 & $* * *$ \\
\hline interactions... & ... SOL x cycle & -.016 & $(.036)$ & & & \\
\hline & ... EU-support party $x$ citizen & .128 & $(.059)$ & $*$ & & \\
\hline & ... Inner-party dissent & .216 & $(.135)$ & & 44.282 & $* * *$ \\
\hline Effects of & $\ldots$ SOL & .466 & $(.101)$ & $* * *$ & 93.124 & $* * *$ \\
\hline interactions & ... SOL $x$ dissent & -.656 & $(.125)$ & $* * *$ & 110.222 & $* * *$ \\
\hline with party & ... SOL x cycle & -.106 & $(.080)$ & & 42.170 & $* * *$ \\
\hline type: gov. & ... EU-support party $\mathrm{x}$ citizen & -.148 & $(.085)$ & + & 45.560 & $* * *$ \\
\hline party $x \ldots$ & ... EU-emphasis opp. parties & -.012 & $(.080)$ & & 37.631 & $* * *$ \\
\hline & ... EU-emphasis gov. parties & .006 & $(.107)$ & & 37.576 & $* * *$ \\
\hline
\end{tabular}

Note: Source: Own data, Linear mixed-effects models, $\mathrm{N}=23$ parties in 7 countries, displayed are coefficients and standard errors in parenthesis; levels of significance: ${ }^{+} \mathrm{p}<.10 ;{ }^{*} \mathrm{p}<.05 ; * * \mathrm{p}<.01 ; * * * \mathrm{p}<.001$. Dependent variable ranges from 0 to $1(100 \%)$. Bold fonts mark significant interaction effects for which margin plots are provided in the Web appendix 
Table 4a: Model 3, Established Parties vs. Challengers (EU mentioned min. twice)

Baseline: EU not mentioned

Coef.

SE sig.

Wald-Chi-Sq

\begin{tabular}{|c|c|c|c|c|c|c|}
\hline \multirow{6}{*}{$\begin{array}{c}\text { Selective } \\
\text { emphasis } \\
\text { model }\end{array}$} & Cat. 1: EU mentioned min. twice & & & & 20.687 & $*$ \\
\hline & Party type & -0.005 & $(.030)$ & & & \\
\hline & Inner party dissent & -0.030 & $(.016)$ & + & & \\
\hline & Strength of leadership (SOL) & 0.006 & $(.014)$ & & & \\
\hline & National election cycle & -0.040 & $(.014)$ & $* *$ & & \\
\hline & EU-support party & 0.012 & $(.014)$ & & & \\
\hline \multirow{6}{*}{$\begin{array}{l}\text { Co- } \\
\text { orientation } \\
\text { model } \\
\text { Structural } \\
\text { controls }\end{array}$} & EU-support citizen & 0.035 & $(.014)$ & $*$ & & \\
\hline & EU-emphasis opp. parties & -0.025 & $(.017)$ & & & \\
\hline & EU-emphasis gov. parties & 0.030 & $(.016)$ & + & & \\
\hline & EU-salience media & -0.027 & $(.012)$ & $*$ & & \\
\hline & Extreme EU-position party & -0.004 & $(.021)$ & & & \\
\hline & constant & 0.081 & $(.041)$ & $*$ & & \\
\hline \multirow{3}{*}{$\begin{array}{c}\text { Effects of } \\
\text { interactions... }\end{array}$} & ... SOL $x$ dissent & 0.021 & (.011) & + & 26.275 & $*$ \\
\hline & $\ldots$ SOL $x$ cycle & -0.008 & $(.016)$ & & & \\
\hline & ... EU-support party $\mathrm{x}$ citizen & 0.004 & $(.011)$ & & & \\
\hline \multirow{7}{*}{$\begin{array}{l}\text { Effects of } \\
\text { interactions } \\
\text { with party } \\
\text { type: estab. } \\
\text { party } x \ldots\end{array}$} & ... Inner-party dissent & -0.021 & $(.027)$ & & 27.273 & $*$ \\
\hline & $\ldots \mathrm{SOL}$ & -0.016 & $(.030)$ & & 26.689 & $*$ \\
\hline & ... SOL $x$ dissent & -0.001 & $(.021)$ & & 26.280 & $*$ \\
\hline & ... SOL $x$ cycle & 0.048 & $(.027)$ & + & 31.248 & $* *$ \\
\hline & ... EU-support party $x$ citizen & 0.025 & $(.028)$ & & 27.446 & $*$ \\
\hline & ... EU-emphasis opp. parties & -0.019 & $(.021)$ & & 27.505 & $*$ \\
\hline & ... EU-emphasis gov. parties & -0.035 & $(.022)$ & & 30.277 & $* *$ \\
\hline
\end{tabular}

Note: Source: Own data, Linear mixed-effects models, $\mathrm{N}=46$ parties in 7 countries, displayed are coefficients and standard errors in parenthesis; levels of significance: ${ }^{+} \mathrm{p}<.10 ;{ }^{*} \mathrm{p}<.05 ; * * \mathrm{p}<.01 ; * * * \mathrm{p}<.001$. Dependent variable ranges from 0 to $1(100 \%)$.

Bold fonts mark significant interaction effects for which margin plots are provided in the Web appendix. 
Table 4b: Model 3, Established Parties vs. Challengers (Distinct EU-scope)

Baseline: EU not mentioned

Coef

SE sig.

Wald-Chi-Sq

\section{Cat. 2: Distinct EU-scope}

Party type

$-.022 \quad(.054)$

Inner party dissent

$-.069 \quad(.029)$

Selective

emphasis

model

Strength of leadership (SOL)

$-.026 \quad(.024)$

National election cycle

$.017 \quad(.026)$

EU-support party

$.023 \quad(.026)$

EU-support citizen

$-.031 \quad(.026)$

Co-

EU-emphasis opp. parties

$.082(.031)$

orientation

model

EU-emphasis gov. parties

$-.031 \quad(.030)$
-.022

Structural

EU-salience media

$-.022 \quad(.021)$

controls

Extreme EU-position party

$-.030 \quad(.038)$

constant

$.334 \quad(.074)$

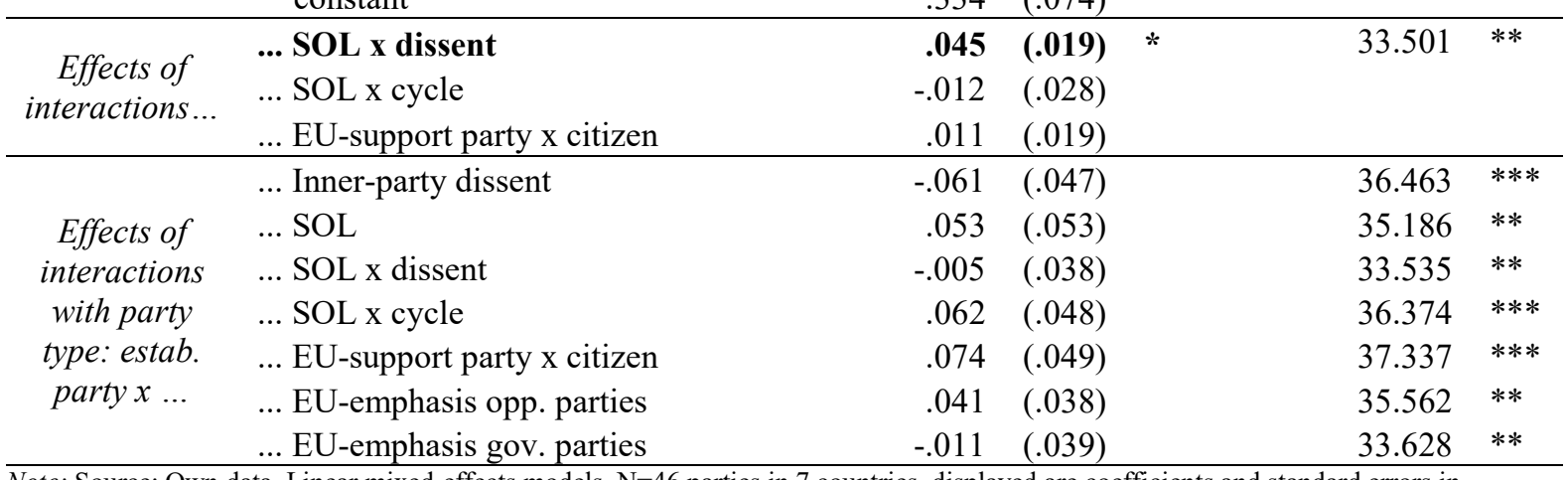

Note: Source: Own data, Linear mixed-effects models, $\mathrm{N}=46$ parties in 7 countries, displayed are coefficients and standard errors in parenthesis; levels of significance: ${ }^{+} \mathrm{p}<.10 ;{ }^{*} \mathrm{p}<.05 ; * * \mathrm{p}<.01 ; * * * \mathrm{p}<.001$. Dependent variable ranges from 0 to $1(100 \%)$.

Bold fonts mark significant interaction effects for which margin plots are provided in the Web appendix. 
Figure 1: Interaction between Strength of Leadership (Electoral Success) and Internal Division by Party Type (Distinct EU-scope)

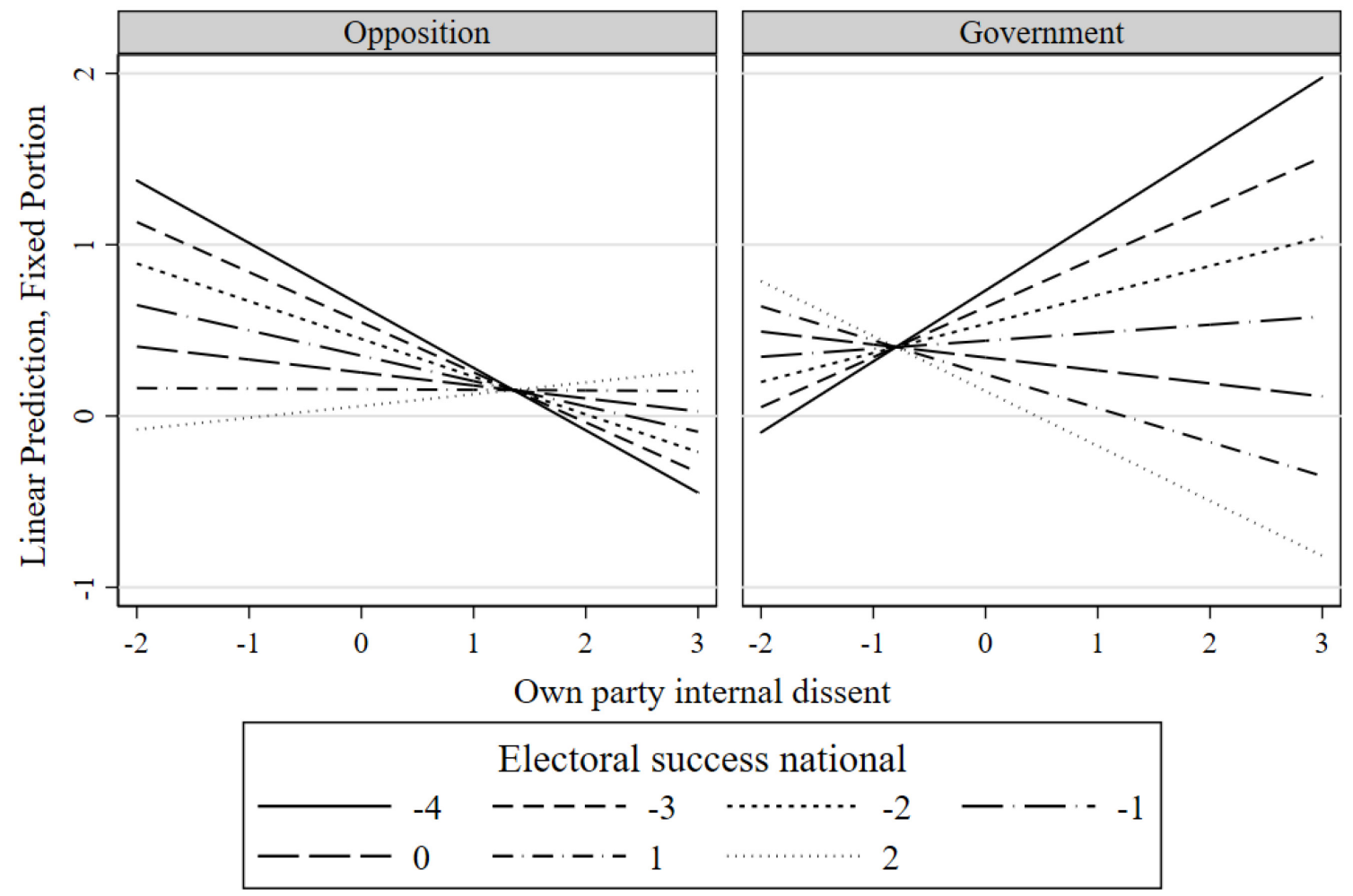

Source: Own data and analysis (Plot for Model 1, Category 2)

Electoral success: High values $=$ gains in votes in last national election (dotted lines).

Internal dissent: High values $=$ high dissent in CHES data (x-axis).

Party Type: Opposition vs. Governing Parties (group variable).

Plotted: Predicted margins in increments of 1 for values from -2 to +3 separated by party type. 
Figure 2: Interaction between Strength of Leadership (Electoral Success) and Internal Division by Party Type (Distinct EU-Scope)

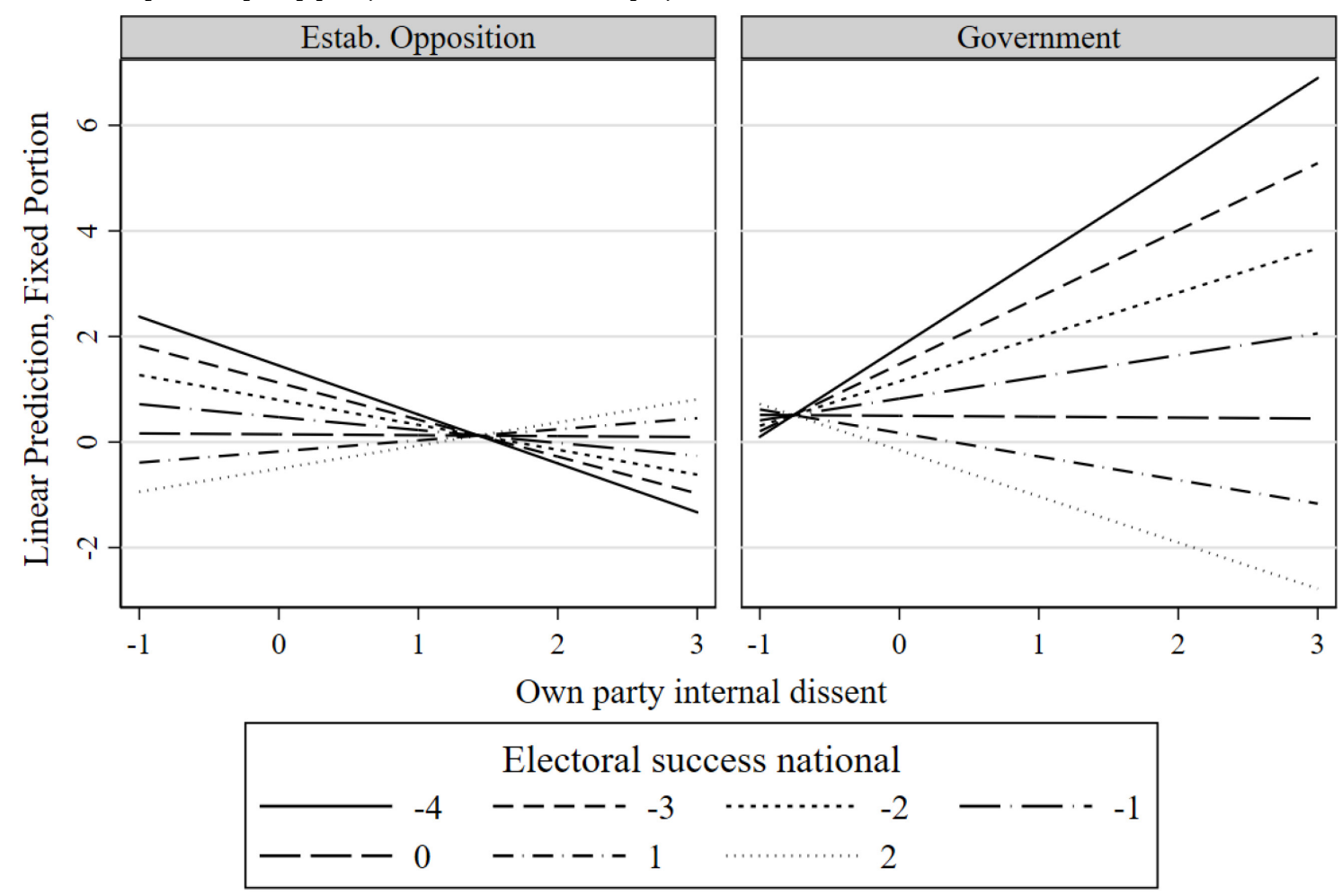

Source: Own data and analysis (Plot for Model 2, Category 2)

Electoral success: High values $=$ gains in votes in last national election (dotted lines).

Internal dissent: High values $=$ high dissent in CHES data (x-axis).

Party Type: Established Opposition vs. Governing Parties (group variable).

Plotted: Predicted margins in increments of 1 for values from -2 to +3 separated by party type. 